\title{
Stock Return Predictability with Financial Ratios
}

\author{
S. Kheradyar, I. Ibrahim, and F. Mat Nor
}

\begin{abstract}
This paper studies whether financial ratios can predict stock returns for the period from January 2000 to December 2009 in Malaysia stock exchange. We select three financial ratios include dividend yield (DY), earning yield (EY) and book-to-market ratio $(\mathrm{B} / \mathrm{M})$ that have been documented to predict stock returns. This study applies generalized least squares (GLS) techniques to estimate the predictive regressions in form of simple and multiple models of panel data sets. The obtained results reveal that the financial ratios can predict stock return, as the $B / M$ has the higher predictive power than $D Y$ and EY respectively. Furthermore, the financial ratios are able to enhance stock return predictability when the ratios are combined in the multiple predictive regression model.
\end{abstract}

Index Terms-Financial ratios, Stock return predictability, Predictive regression, Malaysia stock exchange.

\section{INTRODUCTION}

The Malaysia stock exchange plays an increasingly active role in Malaysia's economic growth. The empirical literature documented evidence that the existence of stock return predictability has significant economic consequences [1]. One possibility is that the stock return predictability contributes to achieve the highest return with the lowest risk, which is attractive for international investors who have a critical role in Malaysia's economic growth. However, to date, academic research in this area is still nascent.

It is fair to say that the profession's view on stock return predictability has been shaped by empirical studies on the U.S. stock market [1]. Therefore, this article contributes to the construct validity of stock return predictability, which is still unknown in emerging markets. In addition, the validity of stock return predictability depends on the sample choice [2]. Thus, to develop the validity of stock return predictability requires more research in various samples. Indeed, the sufficient recognition of the variations between emerging and developed markets helps to improve emerging markets in the world. Generally, this study intends to reaffirm the findings of U.S. stock market based on Malaysia stock market, which is running in an emerging market.

Forty years ago, stock returns were unpredictable because of the overall efficiency of markets [3]. On the contrary, many research studies documented the predictability of stock

Manuscript received July 25, 2011: revised September 13, 2011

The authors thank anonymous referees, conference participants at the 2011 International Conference on Sociality and Economics Development (ICSEP) in Kuala Lumpur, Malaysia for constructive comments.

S. Kheradyar is with the Graduate School of Business, National University of Malaysia-UKM (e-mail: ZP00504@mail2.ukm.my)

I. Ibrahim is with the Graduate School of Business, National University of Malaysia-UKM (e-mail: tdgsb@ukm.my).

F. Mat Nor is with the Graduate School of Business, National University of Malaysia-UKM (e-mail: dgsb@ukm.my). return based on various predictors. Among various predictors, the roles of financial ratios are most important. Such as some main studies found that the book-to-market ratio (B/M) and dividend yield (DY) can strongly predict stock returns [4]-[8], and presented evidence of a return advantage to a low price-to-earnings ratio (the reverse of earning yield (EY) [10], [11]. Moreover, an extensive research improved the stock return predictability with the financial ratios, which included B/M, DY and EY [9].

This paper specifically identified three financial ratios, which are known as the predictor of stock returns in the U.S. market, to test stock return predictability on Malaysia market. The financial ratios include the book-to-market ratio (B/M), dividend yield (DY) and earning yield (EY) which are most useful and effective on stock return predictability in order to cover a wide range of prediction. We formulated eight hypotheses based on the relationship between the three financial ratios and stock returns at two samples. The eight hypotheses dividend into two sets based on their appropriate regression models. An important tool for predicting stock returns is predictive regression, which are applied in two forms, simple and multiple regression models. Both of models are formulated by a panel data set. This study applied generalized least squares (GLS) method to tackle the heteroskedasticity and non-normality distributed residuals.

We find that all the proposed financial ratios predict stock returns in Malaysia market. Similar to U.S. market [5]-[8], the predictive power of $\mathrm{B} / \mathrm{M}$ is higher than other financial ratios. Furthermore, the comparison between the results of simple and multiple predictive regression models indicate that the predictive power of financial ratios are increased when the ratios are combined in the multiple regression model. One possible explanation of the increase in the predictive power of financial ratios of the multiple regression model is that the roles of each financial ratio are unique and complementary because each financial ratio provides specific information, which is used by investors on stock return predictability.

The remainder of the paper is organized as the following. Section II provides a review of the existing literature on stock return predictability with financial ratios. Section III discusses data and methodology for constructing stock return predictors. Section IV provides empirical findings. Section V concludes.

\section{FinanCial RATios AND Stock Returns}

Among the predetermined financial ratios on the predictability of stock returns literature, dividend yield (DY), earning yield (EY) and book-to-market ratio (B/M) have a strong theoretical background based on the predictive models, because the ratios comprised specific characteristics. First, 
each ratio has stock price in the denominator, thus when stocks are overpriced, the ratios present lower value and predict low stock returns. Second, the ratios follow time variation in discount rates, so the ratios should be positively related to discount rates. Third, the statistical properties of the ratios have a big impact on tests of stock return predictability, because the most part of the ratios movements are caused by price changes in the denominator [9]. Finally, financial theories lay great emphasis on the role of risk in stock returns so the relationship between stock returns and financial ratios is because the ratios captured information about the risk. Therefore, these three financial ratios are supported by financial theoretical basis.

\section{A. Dividend Yield (DY) and Stock Return}

According to empirical research, The DY has the predictive power on stock returns [4], as the relationship between DY and return are developed by the appealing patterns [12]. Moreover, DY track variation in return [7] and can predict future return in 36 international markets [13]. To illustrate the predictive power of DY, [9] introduced an explosive new test to improve the predictive ability of financial ratios especially DY during 55 years. Therefore, DY is regarded as a good predictor of stock returns in China [14], Canada [15] and U.S stock market [16]. Consequently, the DY as a strong predictor can contribute to stock return predictability.

\section{B. Earning yield (EY) and Stock Return}

More than seventy years ago, stock price valuated based on the price-to-earnings ratio (the reverse of EY) [17] as the standard method of that era. The seminal works presented evidence of a return advantage to a low price-to-earnings ratio [10], [11] and indicated that stocks with negative price-to-earnings ratios have special risk-return characteristics [5]. The price-to-earnings ratio is arguably the price multiple which frequently cited by the media and used by analysts and investors [18] and the price-to-earnings ratio is doubtless still the most familiar valuation measure today.

The variation in the price-to-earnings ratio (the reverse of EY) are significantly related to the important variables such as expected earnings-growth, expected earnings-risk, dividends per share and dividend payout [19], because the price-earnings ratio effects on the value strategy of market investor [20]. Reference [21] recognized the main factors which effect on the price-earnings ratio through transforming the dividend discount model to the theoretical calculation model.

The empirical literatures laid foundations of the predictive power of EY on stock returns [9], and argued that the earnings yield has independent forecasting power for excess stock returns in addition to the DY [22], [23]. Moreover, EY has the positive relation with stock returns in Malaysia's stock market as an important emerging market [24], thus this study selected EY as the predictor of stock returns.

\section{Book-to-Market Ratio (B/M) and Stock Return}

The positive relationship between return and the ratio of book value of common equity, to market value of common equity that is called the book-to-market ratio $(\mathrm{B} / \mathrm{M})$ indicated by [25] and [26]. However, in the most related research, the use of the book-to-market ratio $(\mathrm{B} / \mathrm{M})$ is motivated by the findings of [5], who indicate the ability of the $B \backslash M$ ratio to explain variation in stock returns.

Considerable evidence suggested that $\mathrm{B} \backslash \mathrm{M}$ ratios are related to future returns [6], and denoted the predictive power of $\mathrm{B} / \mathrm{M}$ ratio on stock returns caused by the relationship between book value and future earnings [8], and provided evidence that the $\mathrm{B} / \mathrm{M}$ ratios predict negative expected returns and track variation in return [7]. The results of recent survey confirmed previous results that the $B \backslash M$ ratio is positively related to stock returns [27]. However, [28] found that the $\mathrm{B} / \mathrm{M}$ ratio has a principal role in the formation of sock returns, and the relationship between stock returns and $\mathrm{B} / \mathrm{M}$ ratio due to the attraction of $\mathrm{B} / \mathrm{M}$ ratio to the implications of market leverage that include the risk factors, which play the effective roles in stock return predictability. Therefore, the $\mathrm{B} / \mathrm{M}$ as a predictor has an explosive impact on stock returns.

\section{DAta AND Methodology}

\section{A. Sampling Design}

This study comprised a period of 10 years, starting from January 2000 to December 2009, and the units of analysis include 960 companies at the end of 2009 that are listed on Malaysia stock exchange (Bursa Malaysia). The filtering process of companies includes five criteria. First, the company must be listed on the Bursa Malaysia main board before 1 January 2000. Second, the stocks of companies must not be suspended for more than 12 months at any time period. Third, the stocks of companies must not be delisted during the period of study. Fourth, the data of all variables for all companies must be available in DataStream. Fifth, the DY of companies must not be zero for more than 12 months at any time period.

Therefore, this study employs a data set of 100 companies that are selected based on the above mentioned five criteria. The selected companies classified into two equal samples, sample (1) and sample (2); because the use of two samples instead of one sample reduces the effects of random sampling errors. Furthermore, two samples produce different estimation of the predictive regressions. These samples which are sorted by the stock price have the advantage for check the stationary of stock returns over different price.

\section{B. Data Description}

Based on our discussion in Section II, three financial ratios are selected as the predictors of stock returns. Here, we briefly describe the construction of each variable. All the variables contain stock price in their calculations. The stock price is the current price taken at the close of market is stored each day. The dependent variable is stock return that is calculated by dividing the current price at the end of each month $(\mathrm{Pt})$ by the current price at the end of last month (Pt-1). The independent variables are $\mathrm{DY}, \mathrm{EY}$ and $\mathrm{B} / \mathrm{M}$ ratios, as the DY is the dividend per share as a percentage of the share price; the EY is the earnings' rate per share divided by the current price at the required date who is a reverse of the price-to-earnings ratio; the $\mathrm{B} / \mathrm{M}$ is defined as the balance sheet value of the common equity in the company per share 
divided by the market value of the common equity per share at the required date who is a reverse ratio of market value to book value. The data source of this study is DataStream, which includes comprehensive source of the external secondary data in financial research. Therefore, the data used are specified by the assumptions of DataStream.

Table I summarizes the mean, median, maximum, minimum and the standard deviation of the variables for both our samples in the panel data sets. The descriptive statistics of the variables present by percentage that reveal the standard deviation of stock return in both samples are close together; therefore, the comparison between the results of two samples is reasonable. Furthermore, the amounts of standard deviations of both samples are lower than U.S market samples. Namely, the standard deviation of U.S market samples is near to $38.8 \%$ [7] in comparison with $9.5 \%$ or $8.2 \%$ in our samples. However, the mean, median and the standard deviation of DY in both samples are near together and almost similar to U.S market samples, while in the B/M on the sample (1) is larger than the sample (2) and U.S market samples.

TABLE I: THE DESCRIPTIVE STATISTICS OF THE VARIABLES IN BOTH SAMPLE

\begin{tabular}{|c|c|c|c|c|}
\hline \multicolumn{5}{|c|}{ Sample (1) } \\
\hline & \multirow{2}{*}{$\begin{array}{c}\text { Dependent Variable } \\
\mathrm{R}\end{array}$} & \multicolumn{3}{|c|}{ Independent Variables } \\
\hline & & DY & $\mathrm{EY}$ & $\mathrm{B} / \mathrm{M}$ \\
\hline Mean & 0.4 & 4.2 & 11.3 & 141 \\
\hline Median & 0 & 3.7 & 10.1 & 125 \\
\hline Maximum & 106 & 22.3 & 83.3 & 625 \\
\hline Minimum & -61 & 0.0 & 0.0 & 11 \\
\hline Std.Dev & 9.5 & 2.6 & 7.1 & 75.3 \\
\hline \multicolumn{5}{|c|}{ Sample (2) } \\
\hline & Dependent Variable & \multicolumn{3}{|c|}{ Independent Variables } \\
\hline & $\mathrm{R}$ & DY & EY & $\mathrm{B} / \mathrm{M}$ \\
\hline Mean & 0.8 & 4.1 & 8.6 & 80 \\
\hline Median & 0.4 & 3.7 & 7.5 & 69 \\
\hline Maximum & 87 & 16.7 & 111 & 400 \\
\hline Minimum & -58 & 0.0 & 0.0 & 3 \\
\hline Std.Dev & 8.2 & 2.4 & 5.6 & 51.3 \\
\hline
\end{tabular}

1) R, DY, EY and B/M are respectively stock return, dividend yield, earning yield and book-to-market ratio.

2) All variables are presented as a percentage.

In panel data analysis, the stationary of the variables are a new topic in econometrics, and the various methods have been developed to test stationary. Hence, this study applied four unit root test methods to examine the stationary of the variables for different lag lengths. At first, this study used the individual unit root tests which include augmented-dickey fuller (ADF), Phillips-Perron (PP) and Im, Pesaran \& Shin (IPS) to test stationary in panel data samples. The results indicated that all the variables display stationary at the level for the lag lengths of 1 to 4 . However, the results of Levin, Lin and Chu (LLC) common unit-root test confirm the results of the individual unit root tests which indicate the existence of stationary series in the panel data sets, except for stock return and earning yield at lag length 4 of sample (1), earning yield at lag length 4 of sample (2), and book-to-market ratio at lag length 1 of sample (2). Overall, the results of panel unit root tests indicate robustness of stationary at the variables of both samples. The results are shown in Table II.

TABLE II: THE UNIT RoOT TESTS OF THE VARIABLES IN BOTH SAMPLES

\begin{tabular}{|c|c|c|c|c|c|c|}
\hline \multirow{2}{*}{$\begin{array}{r}\text { Sample } \\
\text { s }\end{array}$} & \multirow{2}{*}{$\begin{array}{r}\text { Vari } \\
\text { able } \\
\mathrm{s}\end{array}$} & & \multicolumn{3}{|c|}{ Individual unit root tests } & \multirow{2}{*}{ 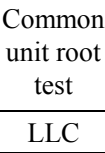 } \\
\hline & & & $\mathrm{ADF}$ & $\mathrm{PP}$ & IPS & \\
\hline \multirow{16}{*}{$\begin{array}{c}\text { Sample } \\
\text { (1) }\end{array}$} & \multirow{4}{*}{$\mathrm{R}$} & 1 & $2355 * * *$ & $3510 * * *$ & $-54.1 * * *$ & $-49.9 * * *$ \\
\hline & & 2 & $1318 * * *$ & $3510 * * *$ & $-34.6 * * *$ & $-21.8 * * *$ \\
\hline & & 3 & $996 * * *$ & $3510 * * *$ & $-28.1 * * *$ & $-10.5 * * *$ \\
\hline & & 4 & $677 * * *$ & $3510 * * *$ & $-21.1 * * *$ & 0.84 \\
\hline & \multirow{4}{*}{ DY } & 1 & $253 * * *$ & $219 * * *$ & $-7.7 * * *$ & $-4.9 * * *$ \\
\hline & & 2 & $254 * * *$ & $219 * * *$ & $-8.0 * * *$ & $-5.1 * * *$ \\
\hline & & 3 & $259 * * *$ & $219 * * *$ & $-7.9 * * *$ & $-4.7 * * *$ \\
\hline & & 4 & $267 * * *$ & $219 * * *$ & $-8.0 * * *$ & $-4.1 * * *$ \\
\hline & \multirow{4}{*}{ EY } & 1 & $371 * * *$ & $347 * * *$ & $-11.5 * * *$ & $-4.7 * * *$ \\
\hline & & 2 & $364 * * *$ & $347 * * *$ & $-11.4 * * *$ & $-3.8 * * *$ \\
\hline & & 3 & $296 * * *$ & $347 * * *$ & $-9.5 * * *$ & $-1.7 * *$ \\
\hline & & 4 & $272 * * *$ & $347 * * *$ & $-9.1 * * *$ & -0.6 \\
\hline & \multirow{4}{*}{$\mathrm{B} / \mathrm{M}$} & 1 & $211 * * *$ & $171 * * *$ & $-6.9 * * *$ & $-5.2 * * *$ \\
\hline & & 2 & $246 * * *$ & $171 * * *$ & $-8.3 * * *$ & $-6.5 * * *$ \\
\hline & & 3 & $236 * * *$ & $171 * * *$ & $-7.9 * * *$ & $-5.6 * * *$ \\
\hline & & 4 & $235 * * *$ & $171 * * *$ & $-7.8 * * *$ & $-5.1 * * *$ \\
\hline \multirow{16}{*}{$\begin{array}{c}\text { Sample } \\
\text { (2) }\end{array}$} & \multirow{4}{*}{$\mathrm{R}$} & 1 & $2144 * * *$ & $3395 * * *$ & $-50.4 * * *$ & $-51.4 * * *$ \\
\hline & & 2 & $1258 * * *$ & $3395 * * *$ & $-33.5 * * *$ & $-28.4 * * *$ \\
\hline & & 3 & $977 * * *$ & $3395 * * *$ & $-27.8 * * *$ & $-19.3 * * *$ \\
\hline & & 4 & $698 * * *$ & $3395 * * *$ & $-21.7 * * *$ & $-10.1 * * *$ \\
\hline & \multirow{4}{*}{ DY } & 1 & $288 * * *$ & $301 * * *$ & $-8.9 * * *$ & $-4.1 * * *$ \\
\hline & & 2 & $250 * * *$ & $301 * * *$ & $-8.4 * * *$ & $-3.6 * * *$ \\
\hline & & 3 & $244 * * *$ & $301 * * *$ & $-8.0 * * *$ & $-2.9 * * *$ \\
\hline & & 4 & $245 * * *$ & $301 * * *$ & $-8.2 * * *$ & $-2.8^{* * *}$ \\
\hline & \multirow{4}{*}{ EY } & 1 & $406 * * *$ & $398 * * *$ & $-11.8 * * *$ & $-4.9 * * *$ \\
\hline & & 2 & $373 * * *$ & $398 * * *$ & $-11.4 * * *$ & $-3.3 * * *$ \\
\hline & & 3 & $300 * * *$ & $398 * * *$ & $-10.0 * * *$ & $-1.9 * *$ \\
\hline & & 4 & $307 * * *$ & $398 * * *$ & $-10.0 * * *$ & -1.1 \\
\hline & \multirow{4}{*}{$\mathrm{B} / \mathrm{M}$} & 1 & $171 * * *$ & $166 * * *$ & $-3.8 * * *$ & -0.6 \\
\hline & & 2 & $209 * * *$ & $166 * * *$ & $-5.2 * * *$ & $-1.9 * *$ \\
\hline & & 3 & $199 * * *$ & $166 * * *$ & $-5.0 * * *$ & $-1.3 *$ \\
\hline & & 4 & $202 * * *$ & $166 * * *$ & $-5.4 * * *$ & $-1.3^{*}$ \\
\hline
\end{tabular}

1) R, DY, EY and B/M are respectively stock return, dividend yield, earning yield and book-to-market ratio.

2) ADF, PP, IPS and LLC are respectively the augmented Dickey-Fuller; Phillips-Perron; Im, Pesaran \& Shin; and Levin, Lin \& Chu panel unit root tests.

3) $q$ is the lag lengths of one to four for each variable that indicate robustness checks.

$4) * *$, and $* * *$ represent respectively significance at $10 \%, 5 \%$ and $1 \%$ levels.

\section{Data Analysis Techniques}

Among the single equation multivariate statistical analysis, panel data analysis is often considered to be an efficient analytical method in handling econometric data. Hence, this research employed the panel data regression techniques. Indeed, the nature of data collected, which are cross-sectional and time-series, is compatible with this technique, as the cross-sectional data reflected in stock returns of the different companies, and the time-series reflected in the changes within stock returns over time in each company. The Ramsey 
RESET test indicates that there is no misspecification of omitted variable, incorrect function forms and correlation between the independent variables and error terms. Hausman specification test applied to recognize appropriate method for the estimation of panel data models. The result of Hausman test indicates the fixed effect method is more appropriate for the data analysis of two independent variables (DY and $\mathrm{B} \backslash \mathrm{M}$ ) rather than random effect method or common constant method, because omitted variables, which differ between cases but are constant over time, are controlled. However, random effect method rather than fixed effect method was deemed more suitable for EY panel data set.

This study applied generalized least squares (GLS) method to correct set of covariance and t-statistic, which would be more efficient than ordinary least square (OLS) method. Moreover, generalized least squares method help to tackle the heteroskedasticity and non-normality distributed residuals. Whereas, the standard errors of the coefficients estimates are incorrect, this study used white's corrected standard errors (white's method) to obtain a correct standard error because white's test does not depend on the normality assumption which might make suitable results. When data are ordered in chronological order, the error on one time period may affect the error on the next time periods, so this study employs the Durbin-Watson (DW) test for recognizing the autocorrelation. The results of DW test indicate no serial correlation in all applied regressions because of the DW test statistic amount is very close to 2 .

\section{Predictive Regression}

The present study hypothesized three financial ratios at two samples that might affect stock returns as in Appendix. The eight hypotheses testing lead to apply the predictive regressions, which are used in the most previous research, as in [29], [5], [30], [31], [7], [8], [9], [32]. The applied predictive regressions are formulated by the panel data sets that are considered to be an efficient analytical method. The eight hypotheses dividend into two sets based on their appropriate regression models.

Therefore, the six of eight null hypotheses $\left(\mathrm{H}_{1}, \mathrm{H}_{2}, \mathrm{H}_{3}, \mathrm{H}_{4}\right.$, $H_{5}$ and $H_{6}$ ), that formulated based on the relationship between future stock returns and each financial ratio in both samples, are tested by simple regression model. Thus, the simple regression model of a panel data set has the following form:

$$
R_{i t}=\beta_{0}+\beta_{i} X_{i(t-1)}+\varepsilon_{i t}
$$

In Where, Rit is the return of $i$ th stock in $t$ time period, $\beta 0$ is the unsystematic predictable constant component or the estimated constant, $\beta \mathrm{i}$ is the predictable coefficient of the $\mathrm{i}$ th stock, $\mathrm{Xi}(\mathrm{t}-1)$ is factor $\mathrm{X}$ (that is referred to financial ratios) of the $\mathrm{i}$ th stock in $\mathrm{t}-1$ time period, cit is the unsystematic error from the predicted Rit terms, $i=1,2,3, \ldots, n$.

Moreover, another two hypotheses (H7 and $\mathrm{H} 8)$ that formulated the relationship between future stock returns and combined financial ratios in both samples are tested by multiple regression model. Thus, the multiple regression model of a panel data set has the following form:

$$
R_{i t}=\beta_{0}+\beta_{i 1} D Y_{i(t-1)}+\beta_{i 2} E Y_{i(t-1)}+\beta_{i 3} B / M_{i(t-1)}+\varepsilon_{i t}
$$

In Where, Rit is the return of $\mathrm{i}$ th stock in $\mathrm{t}$ time period, $\beta 0$ is the unsystematic predictable constant component or the estimated constant, $\beta \mathrm{i} 1$ is the predictable coefficient of the $\mathrm{i}$ th stock for the factor 1 that is DY, $\beta \mathrm{i} 2$ is the predictable coefficient of the $i$ th stock for the factor 2 that is EY, $\beta \mathrm{i} 3$ is the predictable coefficient of the $i$ th stock for the factor 3 that is $\mathrm{B} / \mathrm{M}, \mathrm{DYi}(\mathrm{t}-1)$ is DY factor of $\mathrm{i}$ th stock in $\mathrm{t}-1$ time period, $\mathrm{EYi}(\mathrm{t}-1)$ is $\mathrm{EY}$ factor of $\mathrm{i}$ th stock in $\mathrm{t}-1$ time period, $\mathrm{B} / \mathrm{Mi}(\mathrm{t}-1)$ is $\mathrm{B} / \mathrm{M}$ factor of $\mathrm{i}$ th stock in $\mathrm{t}-1$ time period, eit is the unsystematic error from the predicted Rit terms, $i$ $=1,2,3, \ldots, \mathrm{n}$.

The predictive regressions used the variables which transformed to the natural logarithm, because the natural logarithm helps symmetrically and normality in data distribution. Moreover, the percentage of variance explained of total variance is much bigger than when using other forms of the variables.

\section{FINDINGS}

This research examined the eight hypotheses for two samples by the predictive regression models in the panel data sets. We first apply the simple predictive regression model for testing the six hypotheses as the results summarized in Table III. In the sample (1), the three null hypotheses (H1, H2 and H3) have been rejected, so there are significant relationships between future stock returns and all financial ratios at the 5\% level. In the sample (2), the two hypotheses (H5 and H6) have been rejected at 5\% significant level but the fourth null hypothesis (H4) has been rejected at the $10 \%$ significance level, thus the support evidence of the sample (2) is not as stronger as the sample (1) for the predictive power of DY. According to the findings of [4]-[9], [30]-[32], the results of this study indicate that there is a positive relation between financial ratios and future stock returns. Moreover, the attention to adjusted R2 shows that the predictive power of $\mathrm{B} / \mathrm{M}$ is highest among the financial ratios in both samples. Sequentially, the predictive power of DY is greater than EY.

\begin{tabular}{|c|c|c|c|c|}
\hline & $\beta_{0}$ & $\beta_{i}$ & Adj.R ${ }^{2}(\%)$ & p-value \\
\hline Model $D Y$ & \multicolumn{4}{|c|}{$R_{i t}=\beta_{0}+\beta_{i} D Y_{i(t-1)}+\varepsilon_{i t}$} \\
\hline Sample (1) & -0.024 & 0.018 & 1.26 & 0.018 \\
\hline Sample (2) & -0.007 & 0.009 & 1.11 & 0.062 \\
\hline Model $E Y$ & \multicolumn{4}{|c|}{$R_{i t}=\beta_{0}+\beta_{i} E Y_{i(t-1)}+\varepsilon_{i t}$} \\
\hline Sample (1) & 0.008 & 0.004 & 0.08 & 0.028 \\
\hline Sample (2) & 0.022 & 0.007 & 0.21 & 0.000 \\
\hline Model $B / M$ & \multicolumn{4}{|c|}{$R_{i t}=\beta_{0}+\beta_{i} B / M_{i(t-1)}+\varepsilon_{i t}$} \\
\hline Sample (1) & -0.008 & 0.039 & 2.47 & 0.000 \\
\hline Sample (2) & 0.015 & 0.024 & 1.76 & 0.000 \\
\hline \multicolumn{5}{|c|}{$\begin{array}{l}\text { 1) R, DY, EY and B/M are respectively stock return, dividend yield, } \\
\text { earning yield and book-to-market ratio. } \\
\text { 2) } \beta_{0} \text { is unsystematic predictable constant component or the estimated } \\
\text { constant, } \beta i \text { is the predictable coefficient of the } i \text { th stock, } \varepsilon_{i t} \text { is } \\
\text { unsystematic error from the predicted } R_{i t} \text { terms, } i=1,2,3, \ldots, n \text {. }\end{array}$} \\
\hline
\end{tabular}

TABLE III: THE SIMPLE PREDICTIVE REGRESSION RESUltS

Subsequently, we applied the multiple predictive regression model for testing the last two hypotheses (H7 and 
H8) as the results shown in Table IV. Hausman test result and data structure of variables represent the fixed effect method of the panel data model is the appropriate method to test the multiple predictive regressions. In both samples, the results of the multiple predictive regressions are statistically significant at $1 \%$ level, so the hypotheses ( $\mathrm{H} 7$ and $\mathrm{H} 8$ ) have been rejected. According to the results of previous research in the developed market [4]-[9], this study suggests the combination of the B\M, DY and EY can predict future stock returns, and the slope coefficients of the financial ratios in both samples are positive. Moreover, the coefficients of B/M are the greatest amount in both samples that indicate the variations of $\mathrm{B} / \mathrm{M}$ is more influences on stock returns than the variation of DY and/or EY. It's interesting to compare the adjusted R2 of the multiple predictive model with simple predictive model, because the adjusted R2 is increased when we combined all financial ratios in the multiple regression model. As the result, the combination of the B $\backslash \mathrm{M}, \mathrm{DY}$ and $\mathrm{EY}$ can predict future stock returns stronger than each of them lonely.

TABLE IV: The Multiple Predictive Regression Results

\begin{tabular}{|c|c|c|c|c|c|c|c|}
\hline \multirow[t]{2}{*}{ Model } & \multicolumn{7}{|c|}{$R_{i t}=\beta_{0}+\beta_{i l} D Y_{i(t-1)}+\beta_{i 2} E Y_{i(t-1)}+\beta_{i 3} B / M_{i(t-1)}+\varepsilon_{i t}$} \\
\hline & $\beta_{0}$ & $\beta_{i 1}$ & $\beta_{i 2}$ & $\beta_{i 3}$ & $\begin{array}{r}\text { Adj. } R^{2} \\
(\%)\end{array}$ & DW & P-value \\
\hline $\begin{array}{l}\text { Sample } \\
\text { (1) }\end{array}$ & 0.017 & 0.009 & 0.001 & 0.033 & 2.64 & 1.94 & 0.000 \\
\hline $\begin{array}{l}\text { Sample } \\
\text { (2) }\end{array}$ & 0.019 & 0.003 & 0.003 & 0.023 & 2.16 & 1.94 & 0.000 \\
\hline \multicolumn{8}{|c|}{$\begin{array}{l}\text { 1) R, DY, EY and B/M are respectively stock return, dividend yield, } \\
\text { earning yield and book-to-market ratio. } \\
\text { 2) } \beta_{0} \text { is unsystematic predictable constant component or the estimated } \\
\text { constant, } \beta_{i 1}, \beta_{i 2} \text { and } \beta_{i 3} \text { are respectively the predictable coefficient of } \\
\text { the DY, EY and B/M factors of the } i \text { th stock, } i=1,2,3, \ldots, n \text {. } \\
\text { 3) DW is Durbin-Watson test for recognizing the autocorrelation as the } \\
\text { figures indicates that there is no serial correlation in all applied } \\
\text { regressions because of the DW test statistic is very close to } 2 .\end{array}$} \\
\hline
\end{tabular}

\section{CONCLUSION}

This paper examines the predictive power of three financial ratios on stock returns in Malaysia stock market over ten years from 2000 to 2009 . The previous research documented the role of financial ratios on stock return predictability; however, the most of the studies have been hypothesized to predict U.S. stock returns, thus the predictive power of the financial ratios is still unknown in emerging markets. Among financial ratios, DY, EY and B/M have a strong theoretical background and unique characteristics, as in [9].

This study finds evidence of stock return predictability with financial ratios, emphasizing two main points. First, Similar to the findings of previous research in the developed market, financial ratios are able to predict future stock returns in Malaysia market as an important emerging market. In addition, similar to the results of [5], [6], [7], [8] the predictive power of $\mathrm{B} / \mathrm{M}$ is higher than other financial ratios. Second, the combination of the financial ratios enhances stock return predictability. Therefore, the financial ratios seem to play unique and complementary roles on stock return predictability.

\section{APPENDIX}

Hypotheses

H1: There is no relationship between stock returns of sample (1) in the period $(t)$ and DY in the period $(t-1)$.

$\mathrm{H}_{2}$ : There is no relationship between stock returns of sample (1) in the period (t) and EY in the period (t-1).

H3: There is no relationship between stock returns of sample (1) in the period (t) and B/M in the period (t-1).

$\mathrm{H}_{4}$ : There is no relationship between stock returns of sample (2) in the period (t) and DY in the period (t-1).

$\mathrm{H}_{5}$ : There is no relationship between stock returns of sample (2) in the period (t) and EY in the period (t-1).

$\mathrm{H}_{6}$ : There is no relationship between stock returns of sample (2) in the period (t) and B/M in the period (t-1).

$\mathrm{H}_{7}$ : There is no relationship between stock returns of sample (1) in the period (t) and the combination of DY, EY and $\mathrm{B} / \mathrm{M}$ in the period $(\mathrm{t}-1)$.

$\mathrm{H}_{8}$ : There is no relationship between stock returns of sample (2) in the period (t) and the combination of DY, EY and $\mathrm{B} / \mathrm{M}$ in the period (t-1).

\section{REFERENCES}

[1] A. Schrimpf, "International stock return predictability under model uncertainty," Journal of International Money and Finance, vol. 29, pp. 1256-1282, 2010.

[2] D. Kim, "A reexamination of firm size, book-to-market, earnings price in the cross-section of expected stock returns," Journal of Financial and Quantitative Analysis, vol. 32, no. 4, pp. 389-463, 1997.

[3] E. F. Fama, "Efficient capital markets: a review of theory and empirical work," Journal of Finance, vol. 25, pp. 383-417, 1970.

[4] E. F. Fama, and K. French, "Dividend yields and expected stock return," Journal of Financial Economics, vol. 22, pp. 3-25, 1988.

[5] E. F. Fama, and K. French. "The Cross-Section of Expected Stock Returns," Journal of Finance, vol. 47: 427-465, 1992.

[6] E. F. Fama, and K. French, "Size and book-to-market factors in earnings and returns," Journal of Finance," vol. 50, no.1, pp. 131-155, 1995.

[7] S. P. Kothari, and J. Shanken, "Book-to-market, dividend yield, and expected market returns: a time series analysis," Journal of Financial Economics, vol. 44, pp. 169-203, 1997.

[8] J. Pontiff, and L. Schall, "Book-to-market ratios as predictors of market returns," Journal of Financial Economics, vol. 49, pp. 141-160, 1998.

[9] J. Lewellen, "Predicting Returns with Financial Ratios," Journal of Financial Economics, vol. 74, pp. 209-235, 2004.

[10] J. McWilliams, "Price, earning and P-E ratios," Financial Analysts Journal, vol. 22, no. 3, pp. 137, 1996.

[11] S. Basu, "Investment performance of common stocks in relation to their price-earnings ratios: a test of the efficient market hypothesis," Journal of Finance, vol. 32, no. 3, pp. 663-682, 1977.

[12] R. Hodrick, "Dividend yields and expected stock returns: alternative procedures for inference and measurement," Review of Financial Studies, vol. 5, 357-386, 1992.

[13] N. K. Choudhury, "Does the Dividend Yield Predict International Equity Returns", Working Paper of Duke University, 2003.

[14] Y. Wang, and A.D. Iorio, "The cross-sectional relationship between stock returns and domestic and global factors in the Chinese A-share market", Review Quantitative Finance and Accounting, vol. 29, pp. 181-203, 2007.

[15] R. Deaves, P. Miu, and C. B. White, "Canadian stock market multiples and their predictive content," International Review of Economics and Finance, vol. 17, no. 3, pp. 457-466, 2008.

[16] S. W. Chen, and C. H. Shen, "Is the Stock Price Higher than that Implied by the Fundamentals?," International Research Journal of Finance and Economics, vol. 29, pp. 87-109, 2009.

[17] B. Graham, and D. L. Dodd, "Security analysis," New York: McGraw-Hill Professional Publishing, 1934. 
[18] S. B. Block, "A study of financial analysis: practice and theory," Financial Analysts Journal, vol. 55, no. 4, pp. 86-95, 1999.

[19] R. L. Constand, L. P. Freitas and M. J. Sullivan, "Factors affecting price earnings ratios and market values of Japanese firms," Journal Financial Management, vol. 20, pp. 4, 1991.

[20] M.Y.L. Li, "Value or volume strategy?," Finance Research Letters, vol. 6, no. 4, pp. 210-218, 2009.

[21] Y. Tian, and J. Zheng, "Empirical study on the main factors affecting price-earnings ratio of listed companies in China, Modern finance and global trading cooperation," in Proc. 5th international annual conference on WTO and financial, 2008, pp. 483-486.

[22] J. Y. Campbell, and R. J. Shiller, "Stock Prices, Earnings and Expected Dividends," Journal of Finance, vol. 43, no. 3, pp. 661-676, 1988.

[23] O. Lamont, "Earnings and Expected Returns," Journal of Finance, vol. 53, no. 5, pp. $1563-1587,1998$.

[24] S. T. Lau, T. C. Lee, and T. H. McInish, "Stock Returns and Beta, Firms Size, E/P, CF/P, Book-to-market, and Sales Growth: Evidence from Singapore and Malaysia," Journal of Multinational Financial Management, vol. 12, pp. 207-222, 2002.

[25] D. Stattman, "Book Values and Stock Returns," The Chicago MBA: A Journal of Selected Papers, vol. 4, 1980.

[26] B. Rosenberg, K. Reid, and R. Lanstein, "Persuasive Evidence of Market Inefficiency", Journal of Portfolio Management, vol. 11, 1985.

[27] S. H. Penman, S. A. Richardson, and I. Tun, "The book-to-price effect in stock returns: Accounting for leverage," Journal of Accounting Research, vol. 45, no. 2, pp. 427-467, 2007.

[28] M. Dempsey, "The book-to-market equity ratio as a proxy for risk: evidence from Australian markets," Australian Journal of Management, vol. 35, no. 1, pp. 7-21, 2010.

[29] E. F. Fama, and J. MacBeth, "Risk, return, and equilibrium: empirical tests," Journal of Political Economy, vol. 81, pp. 607-636, 1973.

[30] C. R. Nelson, and M. Kim, "Predictable stock returns: role of small sample bias," Journal of Finance, vol. 48, pp. 641-661, 1993.

[31] R. F. Stambaugh, "Predictive regressions," Journal of Financial Economics, vol. 54, pp. 375-421, 1999.

[32] X. Jiang, and B. S. Lee, "Stock returns, dividend yield, and book-to-market ratio," Journal of Banking and Finance, vol. 31, pp. 455-475, 2007.

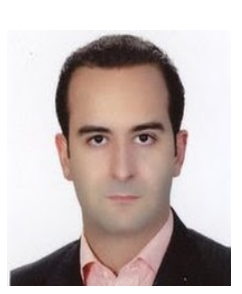

Sina Kheradyar, was born in Iran in 1980. The educational background in the field of Finance and Accounting is listed as following: Master degree, Islamic Azad University, Iran in 2008; Bachelor degree, National University of Iran, Iran in 2003.

$\mathrm{He}$ is Ph.D Candidate of the Graduate School of Business, National University of Malaysia-UKM since 2009. The recent conferences are included first, The First Iranian Students Scientific Conference (ISSC) in Malaysia, Kuala Lumpur, second, 13th Malaysian Finance Association (MFA) Conference in Malaysia, Langkawi, and third, International Conference on Sociality and Economic in Malaysia (ICSEP), Kuala Lumpur in 2011. His areas of research are Investment, Portfolio Management and Corporate Finance.
Mr. Kheradyar is referee and reviewer of the Iranian Students Scientific Conference (ISSC) in Malaysia; A member of the Malaysian Finance Association (MFA), A member of Iranian Students' Scientific Core (ISSC) of economic, finance and accounting, and Chartered Financial Analysis (CFA) Candidate. He was graduated with the Master degree as a top student.

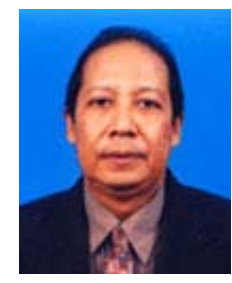

Izani Ibrahim was born in Malaysia in 1958. The educational background in the field of Finance is listed as following: Ph.D. University of Nebraska, U.S.A. in 1996; Master degree, University of Nebraska, U.S.A. in 1992; Bachelor degree, Pennsylvania State University, U.S.A. in 1985.

$\mathrm{He}$ is PROFESSOR and DEPUTY DEAN of graduate school of business, National University of Malaysia, UKM since 2008. His areas of research are Corporate Finance and Investments. He is specialists in econometric methods, derivative markets and investments.

Prof. Ibrahim is reviewer of Capital Market Review since 2002, Jurnal Pengurusan, FEP, UKM (Journal of Management) since 2001, National Accreditation Board since 2001, and Malaysian Finance Associations (MFA) Conferences since 2002. His recent awards include Property Investment and Inflation-Hedging in Residential Property: The Case of District of Gombak, Selangor, Sponsored by Research University Grant in 2007; Purchasing Power Parity, Linking Goods and Assets Markets in OIC Countries, Sponsored by Research University Grant (GUP) in 2007; and The Financial Conglomeration in the East Asian Region, Recent Trends and Implications for Regional Financial Market Development, Sponsored by ASEAN Secretariat in 2006.

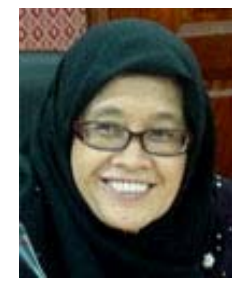

Fauzias Mat Nor was born in Malaysia in 1959. The educational background in the field of Finance is listed as following: Ph.D. University College Dublin in 1992; MBA, University of Miami, Florida, U.S.A. in 1985; and BBA, University of Miami, Florida, U.S.A. in 1984.

She is PROFESSOR and DEAN of graduate school of business, National university of Malaysia, UKM since 2008. Her areas of research are Corporate Finance, Investments, Mergers and Acquisitions.

Prof. Mat Nor is Board of Directors, Asia Pacific Finance Association; Auditor, Pacific Basin Financial Management Society; Editorial Board/Reviewer, Capital Market Review; Reviewer for Asian Academy of Management Journal; President of Malaysian Finance Association (MFA), Reviewer for Asian Academy of Management (AAM) Conference, and APFA conference. Her recent awards include Excellence Service Award, Faculty of Economics and Business in 2006; Fund Generation Award (Workshop and seminar categories as a chairperson) in 1997; and Best Paper Award at the Malaysian Finance Association 4th Annual Symposium in 2002. 